\title{
Mat á járnbúskap með mælingu á transferrínviðtökum
}

\section{Vigfús \\ Porsteinsson ${ }^{1}$ \\ sérfræðingur í \\ blóðmeinafræði og \\ meinefnafræði}

Friðrik E. Yngvason ${ }^{2}$ sérfræðingur í lyf- og lungnalækningum

Lykiloro: járnskortur, transferrínviðtakar, sTfR, blóðrauðamagn í netfrumum.

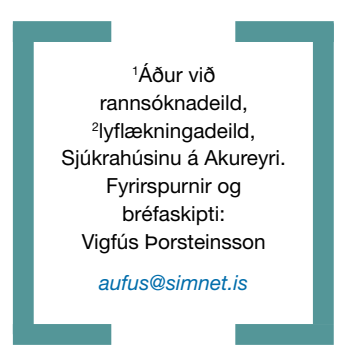

\section{Ágrip}

Inngangur: Tilgangur pessarar könnunar var að bera saman gildi mælinga á transferrínviðtökum í sermi (sTfR) og nokkurra annarra blóðrannsókna við greiningu járnskorts.

Efniviður og aðferðir: Könnunin var framskyggn og öllum sjúklingum sem fljótandi mergsýni var tekið úr á Fjórðungssjúkrahúsinu á Akureyri á tímabilinu 1999 til 2003 var heimil pátttaka. Fullgildir pátttakendur voru 89. Næmi, sértæki, skilvirkni og mælikvarði Youdens við greiningu járnskorts var reiknað fyrir ferritín, $\mathrm{MCV}, \mathrm{CHr}$, sTfR, sTfR-ferritín-vísi, járnmettun transferríns og Tómasartöflu. Járnskortur var skilgreindur sem ekkert sjáanlegt járn við smásjárskoðun á merg.

Niðurstöður: Samkvæmt mælikvarða Youdens reyndist Tómasartafla best við greiningu járnskorts. Hjá pátttakendum sem höfðu CRP <6 $\mathrm{mg} / \mathrm{L}$ og virtust pannig ekki hafa bólgusvörun reyndist hún mjög sértæk en mjög næm hjá peim sem höfðu CRP $\geq 6 \mathrm{mg} / \mathrm{L}$. sTfR-ferritín-vísir reyndist næstbest af samsettum mælikvörðum og af einstökum blóðrannsóknum reyndist sTfR best til að greina járnskort samkvæmt mælikvarða Youdens.

Ályktanir: Í pessari könnun reyndust Tómasartafla og sTfR-ferritín-vísir best við greiningu járnskorts. Notkun pessara mælikvarða getur dregið úr pörf á pví að taka mergsýni til að greina járnskort.

\section{Inngangur}

Blóðleysi er algengt sjúkdómseinkenni og járnskortur er tiltölulega algeng orsök blóðleysis. Greining járnskorts er oft auðveld með hjálp blóðrannsókna og dæmigerðar niðurstöður eru pá til dæmis smá rauð blóðkorn, lækkun á ferritíni og járni en hækkun á transferríni (eða járnbindigetu) í sermi. Greining járnskorts með pessum rannsóknum getur pó verið erfið pegar bólgusvörun er til staðar. Bólgusvörunin getur sjálf valdið blóðleysi með smáum, rauðum blóðkornum, pó að járnbirgðir séu nægar, og bólguboðefni líkamans valda gjarnan lækkun á járni og transferríni en hækkun á ferritíni í sermi. Pegar saman fara bólgusvörun og járnskortur ráða áhrif bólgusvörunarinnar á ofangreinda mælikvarða pannig að dæmigerð áhrif járnskorts koma ekki fram í blóði. Pá parf að nota aðrar aðferðir til að greina járnskort. Stundum er tekið mergsýni og gáð að járni í pví með smásjárskoðun en æskilegra væri að eiga kost á blóðrannsókn sem sagt gæti til um járnskort óháð bólgusvörun. Ein af peim rannsóknum sem koma til greina til pess er mæling á transferrínviðtökum í sermi.

Transferrínviðtakar (TfR) eru prótínviðtakar sem binda transferrín og finnast á yfirborði flestra frumna í líkamanum. Tvær gerðir af TfR eru pekktar, TfR1 og TfR2. Erfðagalli á TfR2 getur valdið járnofgnótt ${ }^{1}$ og verður ekki frekar fjallað um TfR2 í pessari grein. TfR1 hefur hins vegar pýðingu fyrir flutning járns og nýtingu pess í líkamanum og verður hér eftir vísað til pess sem TfR. TfR bindur járnflutningsprótínið transferrín og færir pað ásamt járninu inn í frumuna. Járnið skilst par frá transferríninu og nýtist í frumunni en transferríni er skilað aftur út í blóðrásina og pað endurnýtt. ${ }^{2}$ Járnpörf frumunnar ræour fjölda af TfR sameindum á yfirborði hennar. ${ }^{3}$ Fjöldi TfR er mestur á yfirborði rauðkornskímfrumna (forstiga rauðra blóðkorna) í mergnum par eð pær mynda blóðrauðann og purfa mest af járni af öllum frumum í líkamanum. Járnskortur eykur einnig fjölda TfR á yfirborði frumna. Fjöldi af TfR er pess vegna í hámarki á yfirborði rauðkornskímfrumna pegar pær búa við skort á járni. ${ }^{4}$

TfR finnst líka fljótandi í blóði (sTfR) og magn af STfR stendur í réttu hlutfalli við heildarfjölda TfR á yfirborði frumna í líkamanum. ${ }^{5}$ sTfR eykst pannig í blóði pegar aukning er á rauðkornskímfrumum í mergnum, til dæmis við blóðrof eða blóðmissi, og aukningin verður enn meiri ef járnskortur ríkir. Fleira en fjöldi rauðkornskímfrumna og járnskortur getur haft áhrif á sTfR. ${ }^{4}$ sTfR eykst í seinni hluta meðgöngu vegna TfR í fylgju. Langvinnt eitilfrumuhvítblæði (CLL) og eitilfrumukrabbamein (lymphoma) geta valdið aukningu á sTfR í sermi, fleiri illkynja æxli og mergsjúkdómar geta haft áhrif til hækkunar eða lækkunar og epóetínmeðferð getur valdið hækkun.

Bólgusvörun hefur ekki áhrif á sTfR og mælt hefur verið með mælingu á pví til að greina 
Tafla I. Flokkun eftir tilefni mergsýnatöku og tíoni járnleysis í merg í hverjum flokki. PV = sjálfvakið rauðkornablæði (polycythemia vera), ET = sjálfvakið blóðflagnablæði (essential thrombocythemia).

\begin{tabular}{lccc}
\hline & \multicolumn{2}{c}{ Fjöldi } & \% með járnskort \\
\hline Grunur um eða eftirlit með illkynja sjúkdómi í merg & 32 & 6 \\
\hline Orsakagreining blóðleysis & 20 & 15 \\
\hline Grunur um járnskort & 24 & 38 \\
\hline Grunur um PV eða ET & 4 & 25 \\
\hline Grunur um mergrangvaxtarheilkenni (myelodysplastic syndrome) & 7 & 0 \\
\hline Önnur ástæða eða illa skilgreind ástæða & 2 & 0
\end{tabular}

járnskort hjá sjúklingum með bólgusvörun. ${ }^{4,5}$ Fleiri rannsóknir hafa komið til álita í sama tilgangi, til dæmis sTfR-ferritín-vísir, sem er reiknaður út frá sTfR og ferritíni, CHr (meðalblóðrauðamagn í netfrumum, einnig nefnt RET-He) og aðferð C. Thomas og L. Thomas. Síðastnefnda aðferðin, sem hér er vísað til sem Tómasartöflu, skiptir sjúklingum í fjóra flokka eftir sTfR-ferritínvísi og $\mathrm{CHr}$ og tekur líka mið af CRP til pess að vega upp á móti áhrifum bólgusvörunar á ferritín eins og sést á mynd 1. Tómasartaflan hefur pann kost að geta greint á milli starfræns járnskorts, pað er ófullnægjandi framboðs á járni til rauðkornskímfrumna pó að járnbirgðir séu nægar, og raunverulegs járnskorts og hún getur komið að gagni við val á meðferð við blóðleysi og við mat á árangri af peirri meðferð..$^{6-8} \mathrm{CHr}$ lækkar við járnskort eins og MCV en mun hraðar og eykst aftur í eðlilegt gildi á örfáum dögum pegar rauðkornskímfrumurnar fá aftur nægt járn. ${ }^{9}$ sTfRferritín-vísir hefur verið talinn betri mælikvarði á járnhag en sTfR. ${ }^{3,4}$

Sú könnun sem hér er greint frá var gerð til pess að meta gildi sTfR við greiningu járnskorts samanborið við gildi annarra blóðrannsókna. Notaðar voru niðurstöður úr mergskoðunum sem voru gerðar af öðru tilefni hjá óvöldum hópi sjúklinga með margvíslega sjúkdóma. Járnskortur var talinn til staðar ef ekkert járn sást í mergnum. Mat á járnbirgðum í merg með smásjárskoðun

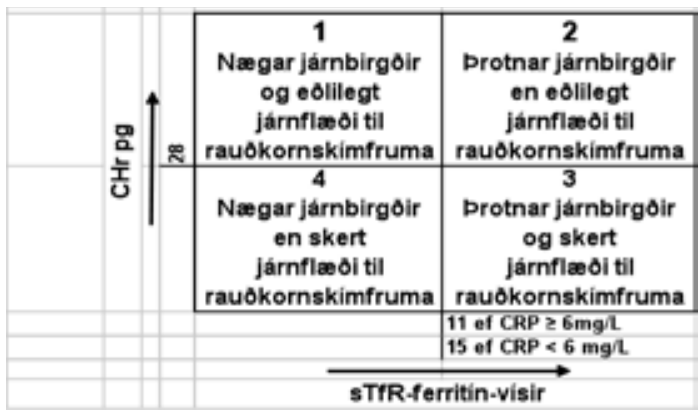

Mynd 1. Tómasartafla. Flokkun C. Thomas og L. Thomas á járnhag eftir niðurstöðum úr mælingum á CHr, sTfRferritin-vísi og CRP. hefur almennt verið talinn góður mælikvarði á járnhag og hefur áður verið notað sem viðmið í hliðstæðum könnunum. ${ }^{3,10-18}$

\section{Efniviður og aðferð̈ir}

Pýði: Allir sjúklingar sem fljótandi mergsýni var tekið úr á Fjórðungssjúkrahúsinu á Akureyri (FSA) á tímabilinu frá nóvember 1999 til október 2003, voru hlutgengir í könnunina, óháð tilefni til mergsýnitökunnar. Könnunin var skýrð fyrir pátttakendum sem staðfestu pátttöku sína með undirskrift. Alls tóku 113 pátt í könnuninni en við úrvinnslu voru 24 ekki teknir með af eftirtöldum ástæðum: Fjórtán vegna pess að mergsýni var ófullnægjandi til mats á járnbirgðum, sjö vegna pess að niðurstöður úr mælingu á sTfR vantaði og prír vegna pess að upplýst sampykki sjúklings vantaði. Á tímabilinu sem könnunin stóð yfir voru tekin 170 fljótandi mergsýni á FSA pannig að $66 \%$ af mögulegum pátttakendum tóku pátt. Orsök pess að ekki tóku fleiri pátt var oftast sú að viðkomandi lækni yfirsást að bjóða pátttöku. Í fáeinum tilvikum var pátttaka ekki boðin vegna pess að sami sjúklingur hafði skömmu áður verið pátttakandi eða vegna pess að ekki reyndist unnt að fá fastandi blóđsýni innan priggja sólarhringa frá töku mergsýnis. Enginn sjúklingur hafnaði pátttöku. Gildir pátttakendur voru 89, 56 konur og 33 karlar. Meðalaldur pátttakenda var 67,4 ár og aldursbil 20-95 ára. Tilefni mergsýnitöku og tíðni járnskorts í hverjum flokki koma fram í töflu I. Aldur, kyn og niðurstöður mergskoðunar og blóðrannsókna hvers pátttakanda voru skráðar en skráning sjúkdómsgreininga og lyfjameðferðar var ekki stöðluð.

Blóðrannsóknir: Blóðsýni voru dregin klukkan 08-10 eftir næturföstu innan priggja sólarhringa fyrir eða eftir töku mergsýnis. Sermi í mælingu á sTfR var geymt við $-70^{\circ} \mathrm{C}$ par til að mælingin var framkvæmd. Aðrar rannsóknir voru að jafnaði framkvæmdar innan sólarhrings. Talning rauðra blóðkorna (RBK) og netfrumna og mælingar á blóðrauða $(\mathrm{Hb})$, meðalstærð rauðra blóðkorna (MCV), stærðardreifingu rauðra blóðkorna (RDW, Red cell Distribution Width) og meðalblóðrauðamagni í netfrumum (CHr) voru gerðar með $\mathrm{H} \cdot 1$ eða H·3 blóðkornateljurum (Bayer Diagnostics, Danmörk) samkvæmt forskrift framleiðanda.

CRP (C reactive protein) var mælt með RAXT efnamæli (Bayer Diagnostics, Danmörk) frá upphafi til nóvember 2000 en síðan með Hitachi 912 efnamæli (Roche Diagnostics, Pýskaland). Prófefni og stýrilausnir frá viðkomandi framleiðendum voru notaðar. Báðar aðferðirnar voru staðlaðar gagnvart sama alpjóðlega staðli og jafngildar. 
Járn var mælt með RA-XT efnamæli frá upphafi til nóvember 2000 en síðan með Hitachi 912 efnamæli. Prófefni og stýrilausnir frá viðkomandi framleiðendum voru notaðar. Báðar aðferðirnar voru staðlaðar gagnvart sama alpjóðlega staðli og jafngildar.

Járnbindigeta var mæld með RA-XT efnamæli frá upphafi til nóvember 2000 en síðan var mælt transferrín með Hitachi 912 efnamæli. Prófefni og stýrilausnir frá viðkomandi framleiðendum voru notaðar. Báðar aðferðirnar voru staðlaðar. Niðurstöður úr mælingum á transferríni í g/L voru margfaldaðar með 25,1 til að fá samanburðarhæfan mælikvarða á járnbindigetu í $\mu$ mól/ L. Mettun járnbindigetu var reiknuð samkvæmt annarri hvorri formúlunni: (a) mettun járnbindigetu $(\%)$ = S-Járn $(\mu \mathrm{mó} / \mathrm{L}) \cdot 100 /$ S-Járnbindigeta ( $\mu$ mól/L) eða (b) mettun járnbindigetu $(\%)$ = SJárn ( $\mu$ mól/L) · 4/S-Transferrín (g/L).

Ferritín var mælt með Elecsys 2010 efnamæli (Roche Diagnostics, Pýskaland) samkvæmt forskrift framleiðanda. Prófefni og stýrilausnir frá framleiðanda tækisins voru notaðar.

sTfR var mælt með prófefnasamstæðunni Quantakine $^{\circledR}$ IVD Soluble Transferrin Receptor ELISA (R\&D Systems Europe, England) samkvæmt forskrift framleiðanda með Multiscan RC 6.0 míkróplötumæli og Wellwash 4 míkróplötupvottavél (Labsystems OY, Finnland). Mælingin byggist á mótefnatækni með samlokuaðferð og ljósmælingu í míkróplötubollum. Tvö einstofna mótefni gegn TfR eru notuð. Annað er bundið í bollunum og bindur sTfR í sýninu á meðan önnur efni eru pvegin 1 burtu. Hitt mótefnið er með áfestan peroxíðasa og binst við sTfR í bollanum. Óbundið mótefni er pvegið í burtu. Peroxíðasavirkni í bollanum er síðan mæld með ljósmælingu og stendur hún í beinu hlutfalli við sTfR í sýninu. Notaðar voru stýrilausnir og eftirlitssýni frá framleiðanda prófefnasamstæðunnar. Mæling á hverju sýni var tvítekin og meðaltal niðurstaðna notað. Breytistuðull (CV) mælingarinnar reyndist 6,7\% innan atrennu við sTfR 28 nmól/L, reiknað út frá mismun milli tvítekninga. Breytistuðull milli daga reyndist $11,5 \%$ við sTfR 27 nmól/L, reiknað á sama hátt.

sTfR-ferritín-vísir (sTfR-F-index) var reiknaður samkvæmt formúlunni: sTfR-ferritín-vísir (nmól/ $\log \mu \mathrm{g})=\operatorname{sTfR}\left(\right.$ nmól/L) $/ \log _{10}$ ferritín $(\mu \mathrm{g} / \mathrm{L})$.

Næmi (sensitivity) er sá hundraðshluti af járnlausum pátttakendum sem tilgreindar forsendur greina rétt sem járnlausa.

Sértæki (specificity) er sá hundraðshluti af pátttakendum með járn í merg sem tilgreindar forsendur greina rétt sem ekki járnlausa.

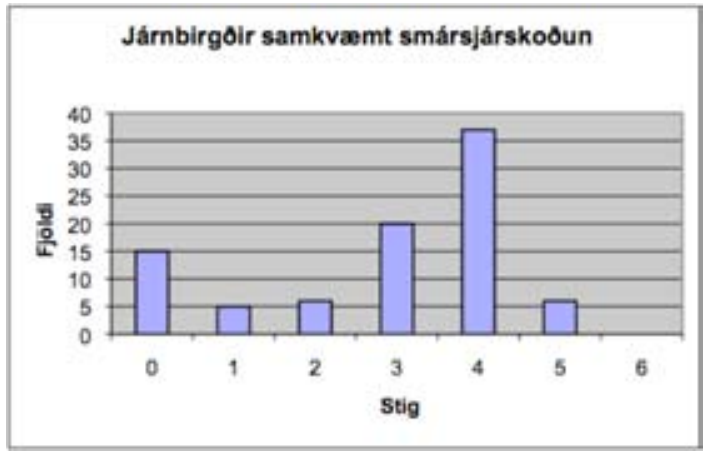

Mynd 2. Dreifing járnbirgða í stigum samkvæmt smásjárskoðun.

Skilvirkni (efficiency) er sá hundraðshluti af pátttakendum sem tilgreindar forsendur flokka rétt sem járnlausa eða ekki járnlausa.

Mælikvarði Youdens (Youden index) var reiknaður samkvæmt formúlunni: mælikvarði Youdens = næmi $(\%) / 100+$ sértæki $(\%) / 100-1$.

Mergrannsóknir: Mergstrok til mats á járnbirgðum voru lituð með prussian-blue aðferð og mótlituð með safranínlit. ${ }^{19}$ Járnbirgðir voru metnar af öðrum höfundi (VP) án vitneskju um niðurstöðu úr mælingu á sTfR. Járnbirgðir voru metnar í stigum frá 0 til 6 samkvæmt forskrift Gales og félaga. ${ }^{20}$ Í stuttu máli eru forsendur stigunarinnar pessar:

\footnotetext{
0 stig Ekkert sjáanlegt járn í mikilli stækkun.

1 stig Litlar járnörður greinanlegar í mikilli stækkun.

2 stig Litlar járnörður sjáanlegar á mörgum svæðum í minni stækkun.

3 stig Margar litlar járnörður um allan merginn.

4 stig Stærri járnörður um allan merginn með tilhneigingu til að renna saman í klumpa.

5 stig Péttir, stórir járnklumpar um allan merginn.

6 stig Mjög mikið af járnklumpum, innan og utan frumna, sem skyggja á mergfrumur.
}

Önnur mergstrok voru lituð með May-GrünwaldGiemsa lit.

Tölfræðiforritið SPSS (SPSS Inc., BNA) var notað við tölfræðiúrvinnslu. Tölfræðilegt marktæki var fundið með $\mathrm{t}$ prófi og miðað við $\mathrm{p}<0,05$. Siðanefnd læknaráðs FSA og Tölvunefnd sampykktu pessa könnun.

\section{Niðurstöður}

Dreifing járnbirgða í merg samkvæmt stigun með smásjárskoðun á járnlituðum mergstrokum kemur fram á mynd 2. Ekkert járn sást í mergnum hjá 15 pátttakendum (17\%) níu konum og sex körlum.

Í töflu II koma fram meðaltöl og staðalfrávik peirra breyta sem skoðaðar voru í pessari könnun, annars vegar hjá sjúklingum án járns í merg (stig 0) og hins vegar hjá sjúklingum með járn í merg (stig 1 til 6) ásamt tölfræðilegu marktæki á 
Tafla II. Meðaltöl og staðalfrávik peirra breyta sem metnar voru í pessari könnun, annars vegar hjá pátttakendum án járns í merg (stig 0) og hins vegar hjá peim sem höfðu járn i merg (stig 1-6) ásamt tölfræðilegu marktæki (p) á mismuninum.

\begin{tabular}{|c|c|c|c|c|}
\hline & Eining & $\begin{array}{c}\text { Sjúklingar án járns } \\
\text { i merg } \\
\text { Meðaltal (staðalfrávik) }\end{array}$ & $\begin{array}{l}\text { Sjúklingar með járn } \\
\text { í merg } \\
\text { Meðaltal (staðalfrávik) }\end{array}$ & $p$ \\
\hline Fjöldi & & 15 & 74 & \\
\hline Konur/karlar & & $9 / 6$ & $47 / 27$ & \\
\hline $\mathrm{Hb}$ & $\mathrm{g} / \mathrm{L}$ & $102,3(30,2)$ & $112,8(21,8)$ & $<0,001$ \\
\hline MCV & $\mathrm{fL}$ & $80,2(10,7)$ & $89,9(5,8)$ & $<0,001$ \\
\hline RDW & $\%$ & $16,35(2,2)$ & $14,62(2,1)$ & $<0,001$ \\
\hline Netfrumur & $10^{9} / \mathrm{L}$ & $49,7(23,8)$ & $46,1(48,5)$ & $0,01-0,02$ \\
\hline $\mathrm{CHr}$ & $\mathrm{pg}$ & $23,81(5,1)$ & $27,79(2,7)$ & $<0,001$ \\
\hline CRP & $\mathrm{mg} / \mathrm{L}$ & $48,7(48,5)$ & $64,9(59,5)$ & $<0,001$ \\
\hline Járn & $\mu \mathrm{mól} / \mathrm{L}$ & $9,1(6,2)$ & $11,2(7,2)$ & $0,001-0,005$ \\
\hline Járnbindigeta & $\mu \mathrm{mól} / \mathrm{L}$ & $72,5(11,5)$ & $49,1(11,9)$ & $<0,001$ \\
\hline $\begin{array}{l}\text { Mettun } \\
\text { járnbindigetu }\end{array}$ & $\%$ & $13,2(10,1)$ & $22,3(12,2)$ & $<0,001$ \\
\hline Ferritín & $\mathrm{mg} / \mathrm{L}$ & $37,2(38,1)$ & $377,6(819,3)$ & $<0,001$ \\
\hline sTfR & nmól/L & $55,1(33,9)$ & $21,7(10,5)$ & $<0,001$ \\
\hline sTfR-ferritín-vísir & nmól/log $\mu \mathrm{g}$ & $53,4(46,9)$ & $10,4(6,7)$ & $<0,001$ \\
\hline
\end{tabular}

mismun. Tölfræðilega marktækur munur $(\mathrm{p}<0,05)$ var á meðaltali allra breytanna.

Samræmi á milli stigunar járnbirgða í merg með smásjárskoðun annars vegar og hins vegar sTfR, sTfR-ferritín-vísis og ferritíns kemur fram á myndum 3-5. Á mynd 3 sést að sTfR mældist marktækt hæst hjá peim sem voru með járnlausan merg en minni munur var á meðaltali sTfR hjá pátttakendum með stig 1 til 5 af járnbirgðum. Mynd

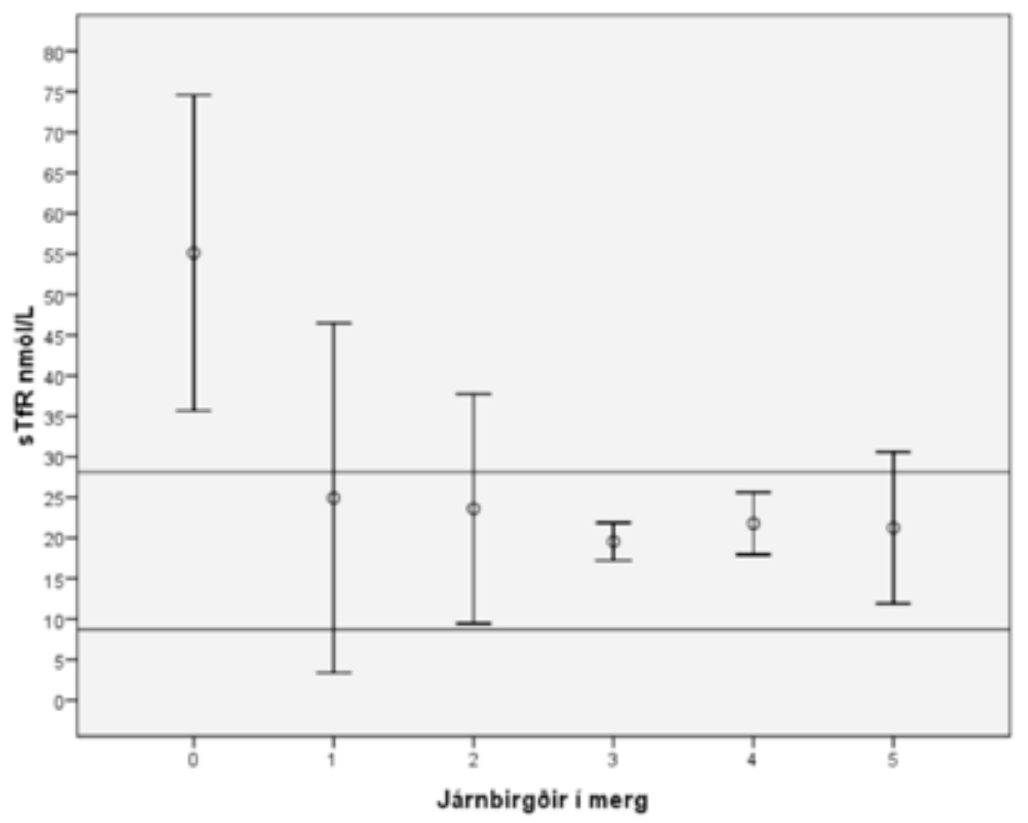

Mynd 3. Meðaltal sTfR og 95\% vikmörk eru sýnd fyrir hvert stig af járnbirgðum i merg. Efri og neðri viðmiðunarmörk eru sýnd með láréttum línum. Tölfræðilega marktækur munu $(p<0,05)$ er á milli sTfR hjá pátttakendum með stig 0 af járnbirgðum og pátttakendum með öll önnur stig og á milli peirra sem eru með stig 1 og stig 3. Ekki er tölfræðilega marktækur munur á milli annarra hópa.
4 sýnir að sTfR-ferritín-vísir var einnig marktækt hæstur hjá járnlausum pátttakendum og fór lækkandi við hvert stig af vaxandi járnbirgðum. Á mynd 5 sést að ferritín var ívið hærra hjá járnlausum pátttakendum en peim sem höfðu stig 1 af járnbirgðum en steig annars marktækt milli stiga með vaxandi járnbirgðum.

Tveir pátttakendur höfðu sTfR undir viðmiðunarmörkum prófefnasamstæðunnar sem notuð var (8,7-28,1 nmól/L samkvæmt upplýsingum framleiðanda). Annar peirra var á frumueyðandi meðferð (cytostatica) og fækkun á rauðkornskímfrumum í merg kom fram við smásjárskoðun hjá hinum. sTfR var yfir viðmiðunarmörkum hjá 23 pátttakendum og 11 peirra voru með járnlausan merg. Af hinum 12 voru sjö með aukningu á rauðkornskímfrumum í merg samkvæmt smásjárskoðun, prír voru með eitilkrabbamein (lymphoma) og einn var á epóetínmeðferð. Engin nærtæk skýring fannst á hækkun á sTfR hjá einum pátttakanda sem mældist með sTfR 36,8 nmól/L. Fjórir járnlausir pátttakendur höfðu sTfR innan viðmiðunarmarka.

Af peim pátttakendum sem reyndust járnlausir samkvæmt smásjárskoðun voru 13 af 14 (93\%) rétt flokkaðir samkvæmt Tómasartöflu (einn járnlausan pátttakanda var ekki hægt að flokka vegna pess að niðurstöðu úr mælingu á $\mathrm{CHr}$ vantaði), 10 voru í flokki 3, prír í flokki 2 og einn ranglega í flokki 1. Af pátttakendum með járn í merg flokkaði Tómasartafla 13 af 71 (18\%) ranglega sem járnlausa, níu í flokk 3 og fjóra í flokk 2.

Í töflu III birtast næmi, sértæki, skilvirkni og mælikvarði Youdens fjögurra stakra blóðrannsókna, ferritíns, $\mathrm{MCV}, \mathrm{CHr}$ og sTfR, og priggja reiknaðra mælikvarða, sTfR-ferritín-vísis, mettunar járnbindigetu og Tómasartöflu, við greiningu járnleysis. Pær forsendur sem reyndust skilvirkastar í óskiptu pýði án tillits til bólgusvörunar voru notaðar við útreikningana. Í töflunni eru pátttakendur með annars vegar CRP $<6 \mathrm{mg} / \mathrm{L}$ og hins vegar $\geq 6 \mathrm{mg} / \mathrm{L}$ skoðaðir sérstaklega til pess að meta áhrif bólgusvörunar.

\section{Umræða}

Á myndum 3-5 sést að sTfR-ferritín-vísir og sTfR greina allvel algert járnleysi en gefa ekki að öðru leyti miklar upplýsingar um magn af járnbirgðum á meðan ferritín er fyrst og fremst mælikvarði á magn af forðajárni en greinir síður á milli algers járnleysis og lægsta stigs af járnbirgðum. Forspárgildi ferritínmælinga um járnleysi takmarkast einnig vegna pess að ferritín eykst í blóði við bólgusvörun og verður pá hærra en svarar til járnbirgða. Næmi ferritíns við greiningu járnskorts 
er pess vegna lítið pó að sértækið sé gott, 97\% 1́ pessari könnun ef miðað er við <20 $\mu \mathrm{g} / \mathrm{L}$. Mjög lágt ferritín bendir pannig eindregið til lítilla eða engra járnbirgða en eðlilegt eða hátt ferritín útilokar ekki járnleysi. $\mathrm{CHr}<23$ pg er einnig mjög sértækur mælikvarði á járnleysi, 99\%, og sTfRferritín-vísir >18 og Tómasartafla fylgir á eftir með 92\% sértæki. Með pví að nota aðrar forsendur mætti enn auka sértækið á kostnað næmis eða öfugt. Ef til dæmis væri miðað við forsendurnar S-Ferritín $<12 \mu \mathrm{g} / \mathrm{L}, \mathrm{MCV}<76$ fL eða CHr $<21$ pg yrði sértæki pessara rannsókna 100\% pví að allir pátttakendur sem höfðu svo lágar niðurstöður reyndust járnlausir við smásjárskoðun. Næmið félli hins vegar undir $50 \%$.

Skilvirkni rannsókna segir til um hve oft pær segja rétt til um pað atriði sem peim er ætlað að skera úr um, í pessari könnun járnhag. Skil-virkni peirra rannsókna, sem hér er fjallað um, reyndist 76-91\% hjá öllum pátttakendum án tillits til bólgusvörunar miðað við forsendurnar í töflu III. Ferritín $<20 \mu \mathrm{g} / \mathrm{L}$ og $\mathrm{CHr}<23$ pg reyndust skilvirkustu einstöku rannsóknirnar. Af reiknuðum mælikvörðum var sTfR-ferritín-vísir skilvirkastur. Ferritín reyndist skilvirkari mælikvarði á járnskort en sTfR í pessari könnun. Í öðrum könnunum, par sem pessar rannsóknir hafa verið bornar saman, hefur sTfR reynst betri en ferritín í sumum ${ }^{10,16,21-23}$ en ekki í öðrum, ${ }^{15,17,18}$ ef til vill vegna mismunandi pýðis.

Kannað var hvort bólgusvörun hefði áhrif á notagildi rannsóknanna með pví að athuga næmi, sértæki og skilvirkni peirra við greiningu járnskorts auk mælikvarða Youdens hjá pátttakendum með CRP annars vegar $<6 \mathrm{mg} / \mathrm{L}$ og hins vegar $\geq 6$ $\mathrm{mg} / \mathrm{L}$. Í töflu III sést að sértæki allra rannsóknanna var mjög gott, 90-100\%, hjá peim sem höfðu CRP $<6 \mathrm{mg} / \mathrm{L}$ en ekki eins gott hjá hinum. Næmi og skilvirkni rannsóknanna voru hins vegar síðri og áhrif bólgusvörunar á pá pætti mismunandi eftir rannsóknum. Munur á næmi, sértæki, skilvirkni eða mælikvarða Youdens milli peirra sem höfðu CRP $<6$ og $\geq 6 \mathrm{mg} / \mathrm{L}$ var pó sjaldan tölfræðilega marktækur eins og kemur fram í töflu III.

Mælikvarði Youdens (Youden index) segir til um notagildi rannsókna við greiningu sjúkdóms eða sjúklegs ástands. ${ }^{24}$ Hann hækkar með vaxandi notagildi og getur hæst orðið 1,00. Af peim rannsóknum sem pessi könnun nær til reyndist Tómasartafla hafa mest notagildi samkvæmt mælikvarða Youdens, 0,75 í óskiptu pýði án tillits til CRP. Hún spáði fyrir um járnskort með 100\% næmi hjá pátttakendum með CRP $\geq 6 \mathrm{mg} / \mathrm{L}$ og $100 \%$ sértæki hjá peim sem voru með CRP <6 mg/L. Af pví má álykta að óhætt sé að treysta niðurstöðum sem gefa til kynna járnskort hjá peim

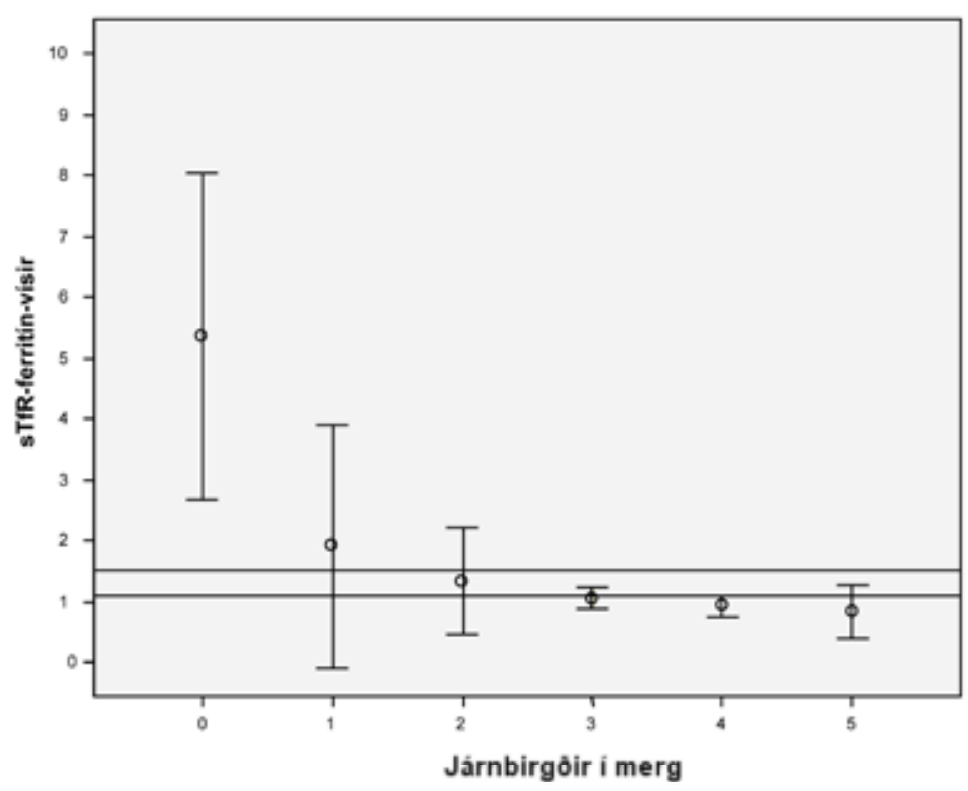

sem hafa CRP $<6 \mathrm{mg} / \mathrm{L}$ og sömuleiðis niðurstöðum sem benda ekki til járnskorts hjá peim sem eru með CRP $\geq 6 \mathrm{mg} / \mathrm{L}$ pegar Tómasartafla er notuð. Tekið skal fram að enginn af pátttakendunum hafði merki um Miðjarðarhafsblóðleysi (thalassaemia) sem getur eins og járnskortur valdið blóðleysi með smáum rauðum blóðkornum. Næst að notagildi kom sTfR-ferritín-vísir sem reyndist aðeins síðri en Tómasartafla, bæði í óskiptu pýði og hjá pátttakendum með CRP $\geq 6 \mathrm{mg} / \mathrm{L}$. Hjá pátttakendum sem höfðu CRP $<6 \mathrm{mg} / \mathrm{L}$ var sTfR-ferritín-vísir hins vegar aðeins betri mælikvarði á járnskort en Tómasartafla samkvæmt mælikvarða Youdens.

Samkvæmt pessu gefur Tómasartafla haldbetri upplýsingar um járnhag en hinar rannsóknirnar.

Mynd 4. Meðaltal sTfRferritín-vísis og $95 \%$ vikmörk eru sýnd fyrir hvert stig af járnbirgðum i merg. Viðmiðunarlínur fyrir sTfR-ferritín-vísi 11 og 15 eru sýndar. Tölfræðilega marktækur munur ( $p$ $<0,05)$ er á milli meðaltals af sTfR-ferritín-vísi hjá pátttakendum meðöll stig af járnbirgðum.

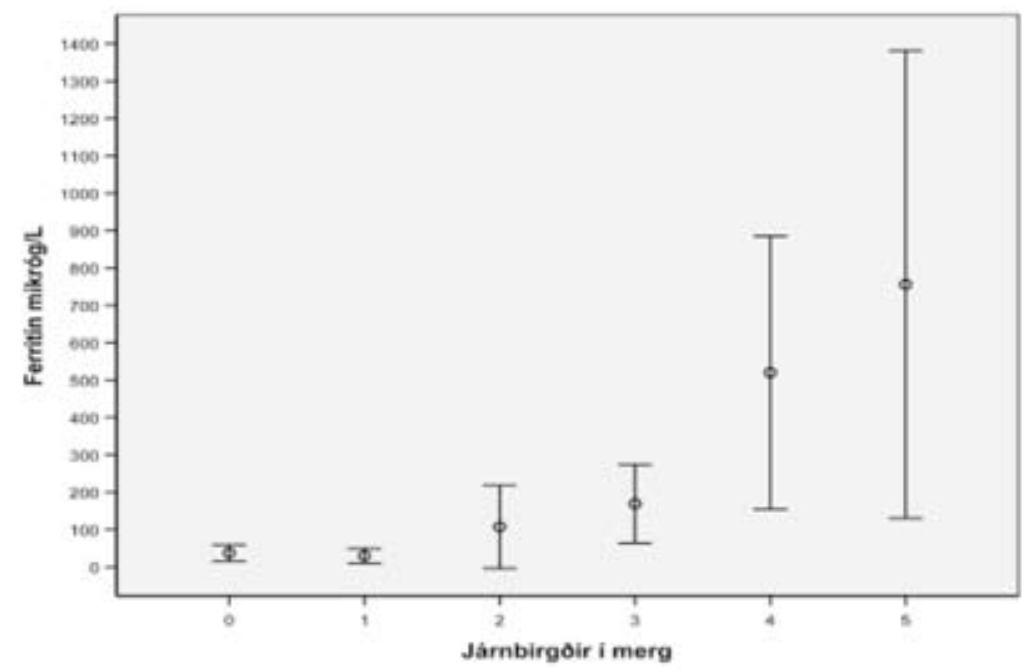

Mynd 5. Meðaltal ferritíns og 95\% vikmörk eru sýnd fyrir hvert stig af járnbirgðum i merg. Tölfræðilega marktækur munur $(p<0,05)$ er á milli meðaltals ferritíns hjá pátttakendum með öll stig af járnbirgðum. 
Tafla III. Tölfræðilega marktækur munur á næmi, sértæki, skilvirkni eða mælikvarða Youdens hjá peim sem hafa CRP <6 mg/L og peim sem hafa CRP $\geq 6$ $m g / L$.

\begin{tabular}{|c|c|c|c|c|c|c|c|c|c|c|c|c|}
\hline & \multicolumn{4}{|c|}{$\begin{array}{l}\text { Allir pátttakendur, } 89 \\
\text { Án tillits til CRP }\end{array}$} & \multicolumn{4}{|c|}{$\begin{array}{l}60 \text { pátttakendur } \\
\mathrm{CRP} \geq 6 \mathrm{mg} / \mathrm{L}\end{array}$} & \multicolumn{4}{|c|}{$\begin{array}{l}29 \text { pátttakendur } \\
\mathrm{CRP}<6 \mathrm{mg} / \mathrm{L}\end{array}$} \\
\hline & Næmi & Sértæki & Skilvirkni & Mælikvarði & Næmi & Sértæki & Skilvirkni & Mælikvarði & Næmi & Sértæki & Skilvirkni & Mælikvarði \\
\hline & $\%$ & $\%$ & $\%$ & Youdens & $\%$ & $\%$ & $\%$ & Youdens & $\%$ & $\%$ & $\%$ & Youdens \\
\hline Ferritín $<20 \mu \mathrm{g} / \mathrm{L}$ & 60 & 97 & 91 & 0,57 & 50 & 96 & 90 & 0,46 & 67 & 100 & 90 & 0,67 \\
\hline $\mathrm{MCV}<84 \mathrm{fL}$ & 60 & 89 & 84 & 0,49 & 83 & 87 & 87 & 0,70 & $44^{*}$ & 90 & 76 & 0,34 \\
\hline $\mathrm{CHr}<23 \mathrm{pg}$ & 43 & 99 & 89 & 0,42 & 43 & 99 & 89 & 0,42 & 33 & 100 & 79 & 0,33 \\
\hline sTfR >25,0 nmól/L & 80 & 80 & 80 & 0,60 & 67 & 76 & 75 & 0,43 & $89^{*}$ & 90 & 90 & 0,79 \\
\hline sTfR-ferritín-vísir > 18 & 80 & 92 & 90 & 0,72 & 67 & 89 & 87 & 0,56 & $89^{*}$ & 100 & 96 & 0,89 \\
\hline $\begin{array}{l}\text { Mettun járnbindigetu } \\
<12 \%\end{array}$ & 60 & 80 & 76 & 0,40 & 67 & 72 & 72 & 0,39 & 56 & $100^{*}$ & 86 & 0,56 \\
\hline Tómasartafla & 93 & 82 & 84 & 0,75 & 100 & 69 & 73 & 0,69 & 86 & 100 & 94 & 0,86 \\
\hline
\end{tabular}

Hún byggist á pví að mæla samtímis sTfR, ferritín, CHr og CRP, reikna sTfR-ferritín-vísi og skipta sjúklingunum í fjóra flokka eins og kemur fram á mynd 1.

Í flokki 1 er meirihluti sjúklinga með blóðleysi vegna bólgusvörunar (anemia of chronic disorder, anemia of infection) og einnig sjúklingar með blóðleysi af ýmsum öðrum orsökum, til dæmis sumir sjúklingar með krabbamein, nýrnabilun og innkirtlasjúkdóma.

Í flokki 2 eru peir sem hafa engar eða hverfandi litlar járnbirgðir en mynda enn eðlileg rauð blóðkorn, hvort sem peir eru nýlega búnir að tapa járnbirgðum en hafa enn nægilegt járn til að mynda blóðrauða eða hafa járntekju sem dugar til myndunar blóðrauða en ekki til að byggja upp járnforða. Í flokk tvö lenda ennfremur sjúklingar sem hafa nægar járnbirgðir en aukna myndun rauðra blóðkorna, til dæmis vegna blæðingar eða blóðrofs, og líka konur í síðari hluta meðgöngu.

Í flokki 3 eru sjúklingar með dæmigert járnskortsblóðleysi.

Í flokki 4 eru sjúklingar með blóðleysi vegna ófullnægjandi framboðs af járni til rauðkornskímfrumna pó að járnbirgðir séu nægar. Рað ástand hefur verið nefnt starfrænn járnskortur (functional iron deficiency) og stafar einkum af truflun á flutningi járns úr járnbirgðum til rauðkornskímfrumna. Sjúklingar í pessum flokki hafa oft gagn af járngjöfum, með eða án epóetíns. Honum tilheyra sumir sjúklingar með blóðleysi vegna bólgusvörunar eða nýrnabilunar og sumir sjúklingar sem fá lyfjameðferð gegn krabbameini. Miðjarðarhafsblóðleysi (thalassemia) tilheyrir einnig pessum flokki.

Mælt hefur verið með járngjöf hjá öllum sjúklingum í flokki 3, hjá öðrum í flokki 2 en punguðum konum, sjúklingum með fjölgun á netfrumum og sjúklingum með mergrangvaxtarheilkenni (myelodysplastic syndrome) og hjá peim sjúklingum í flokki 4 sem fá epóetín til pess að bæta úr blóðleysinu. ${ }^{6-8}$ Árangur af járngjöf getur komið fram í pví að CHr eykst og/eða að sTfRferritín-vísir lækkar pannig að hnit sjúklingsins hliðrast upp á við og/eða til vinsri á mynd 1, jafnvel á milli flokka og flytjast pá í flokk með hærra CHr eða lægri sTfR-ferritín-vísi. Ef hnit sjúklings sem fær epóetín hliðrast í gagnstæða átt getur pað bent til pess að starfrænn járnskortur sé til staðar og pá gæti betri árangur fengist með pví að auka járngjöf eða bæta henni við meðferðina.7,8

Í vafatilvikum má hafa gagn af mælingu á $\mathrm{CHr}$ til að greina á milli blóðleysis af völdum járnskorts og blóðleysis af öðrum orsökum með pví að gá hvernig $\mathrm{CHr}$ breytist við járngjöf. ${ }^{25}$ Pá er $\mathrm{CHr}$ mælt fyrir járngjöf og aftur nokkru síðar. Ef marktæk hækkun verður á CHr staðfestir pað járnskort og gefur tilefni til frekari járngjafar. Pessa nálgun má ef til vill nýta sér við orsakagreiningu blóðleysis og byrja á pví að mæla CHr. Ef niðurstaðan er <21 pg telst raunverulegur járnskortur staðfestur (ef sjúklingurinn er af erlendum uppruna parf fyrst að útiloka Miðjarðarhafsblóðleysi). Sé niðurstaðan $>28$ pg virðist járnskortur ekki vera orsök blóðleysis. ${ }^{6-8}$ Ef CHr er 21-28 pg gæti Tómasartafla komið að gagni við að greina á milli starfræns og raunverulegs járnskorts. Einnig mætti gefa járn og mæla CHr aftur eftir til dæmis 2-4 daga eftir járngjöf í æð eða 1-2 vikur eftir járngjöf um munn. Ef CHr mælist pá eðlilegt eða að minnsta kosti 2 pg hærra en áður bendir pað til járnskorts en greinir ekki á milli starfræns og raunverulegs járnskorts. Notagildi pessarar aðferðar parf að sannreyna áður en hægt er að fullyrða hve mikið pað er.

Nokkur atriði draga úr gildi pessarar könnunar. Pátttakendur voru tilltölulega fáir og vægi niðurstaðna par af leiðandi minna en ella. Mat á járnbirgðum í merg með smásjárskoðun er háð skoðanda og æskilegt hefði verið að fleiri en einn hefði rannsakað mergstrokin með tilliti til járnbirgða. Ekki var í öllum tilvikum athugað 
hvort pátttakendur fengu járnmeðferð, sem getur skekkt péttni ferritíns í sermi til hækkunar, eða krabbameinsmeðferð sem getur haft áhrif á sTfR og CHr. Pað skal einnig haft í huga að ekki er enn til alpjóðlegur staðall fyrir mælingu á sTfR pannig að niðurstöður úr mælingum á sTfR með mismunandi aðferðum eru ekki alltaf sambærilegar. Par að auki eru notaðar mismunandi einingar við mælingar á sTfR sem eykur enn á ósamræmið.

\section{Samantekt}

Hjá sjúklingum með bólgusvörun er oft erfitt að greina járnskort með blóðrannsóknum. Af peim blóðrannsóknum sem fjallað er um í pessari könnun reyndust Tómasartafla og sTfRferritín-vísir vera áreiðanlegustu mælikvarðarnir á járnskort. Fyrrnefnda aðferðin skipar sjúklingum í fjóra flokka eftir járnhag og er sögð gagnleg við val á meðferð við blóðleysi og til pess að meta árangur af peirri meðferð. Notkun pessara mælikvarða getur dregið úr pörf á pví að taka mergsýni til pess að meta járnbirgðir.

\section{Pakkir}

Vísindasjóður læknaráðs FSA fær pakkir fyrir styrk til könnunarinnar. Guðlaug H. Ísaksdóttir, lífeindafræðingur, fær pakkir fyrir mælingar á sTfR.

\section{Heimildir}

1. Mattman A, Huntsman D, Lockitch G, et al. Transferrin receptor 2 (TfR2) and HFE mutational analysis in non-C282Y iron overload: identification of a novel TfR 2 mutation. Blood 2002; 100: 1075-7.

2. Worwood M. Serum transferrin receptor assays and their application. Ann Clin Biochem 2002; 39: 221-30.

3. Punnonen K, Irjala K, Rajamäki A. Serum transferrin receptor and its ratio to serum ferritin in the diagnosis of iron deficiency. Blood 1997; 89: 1052-7.

4. Beguin Y. Soluble transferrin receptor for the evaluation of erythropoiesis and iron status. Clin Chim Acta 2003; 329: $9-22$

5. Feelders RA, Kuiper-Kramer EPA, van Eijk HG. Structure, function and clinical significance of transferrin receptors. Clin Chem Lab Med 1999; 37: 1-10.

6. Thomas C, Thomas L. Anemia of chronic disease: pathophysiology and laboratory diagnosis. Lab Hematol 2005; 11: 14-23.
7. Thomas C, Thomas L. Biochemical markers and hematologic indices in the diagnosis of functional iron deficiency. Clin Chem 2002; 48: 1066-76.

8. Thomas C, Kirschbaum A, Boehm D, Thomas L. The diagnostic plot: a concept for identifying different states of iron deficiency and monitoring the response to epoetin therapy. Med Oncol 2006; 23: 23-36.

9. Cook JD. Diagnosis and management of iron-deficiency anaemia. Best Pract Res Clin Haematol 2005; 18: 319-32.

10. Baillie FJ, Morrison AE, Fergus I. Soluble transferrin receptor: a discriminating assay for iron deficiency. Clin Lab Haematol 2003; 25: 353-7.

11. Das Gupta A, Abbi A. High serum transferrin receptor level in anemia of chronic disorder indicates coexistent iron deficiency. Am J Hematol 2003; 72: 158-61.

12. Juncà J, Fernández-Avilés F, Oriol A, et al. The usefulness of the serum transferrin receptor in detecting iron deficiency in the anemia of chronic disorders. Haematologica 1998; 83: 676-80.

13. Ervasti M, Kotisaari S, Romppanen J, Punnonen K. In patients who have stainable iron in the bone marrow an elevated plasma transferrin receptor value may reflect functional iron deficiency. Clin Lab Haematol 2004; 26: 2059.

14. Means RT, Allen J, Sears DA, Schuster SJ. Serum soluble transferrin receptor and the prediction of marrow aspirate iron results in a heterogenous group of patients. Clin Lab Haematol 1999; 21: 161-7.

15. Joosten E, Van Loon R, Billen J, Blanckaert N, Fabri R, Pelemans W. Serum transferrin receptor in the evaluation of the iron status in elderly hospitalized patients with anemia. Am J Hematol 2002; 69: 1-6.

16. Hanif E, Ayyub M, Anwar M, Ali W, Bashir M. Evaluation of serum transferrin receptor concentration in diagnosis and differentiating iron deficiency anaemia from anaemia of chronic disorder. J Pak Med Assoc 2005; 55: 13-6.

17. Lee EJ, Oh EJ, Park YJ, Lee HK, Kim BK. Soluble transferrin receptor (sTfR), ferritin, and sTfR/log ferritin index in anemic patients with nonhematologic malignancy and chronic inflammation. Clin Chem 2002; 48: 1118-21.

18. Song JS, Park W, Bae SK, et al. The usefulness of serum transferrin receptor and ferritin for assessing anemia in rheumatoid arthritis: comparison with bone marrow iron study. Rheumatol Int 2001; 21: 24-9.

19. Dacie JV, Lewis SM. Practical Haematology, 6. útgáfa. Churchill Livingstone 1984

20. Gale E, Torrance J, Bothwell T. The quantitative estimation of total iron stores in human bone marrow. J Clin Invest 1963; 42: 1076-82

21. Markovi M, Majki -Singh N, Subota V. Usefulness of soluble transferrin receptor and ferritin in iron deficiency and chronic disease. Scand J Clin Lab Invest 2005; 65: 571-6.

22. Vernet M, Doyen C. Assessment of iron status with a new fully automated assay for transferrin receptor in human serum. Clin Chem Lab Med 2000; 38: 437-42.

23. O’Broin S, Kelleher B, Balfe A, Mc Mahon C. Evaluation of serum transferrin receptor assay in a centralized iron screening service. Clin Lab Haematol 2005; 27: 190-4.

24. Fluss R, Faraggi D, Reiser B. Estimation of the Youden Index and its associated cutoff point. Biom J 2005; 47: 458-72.

25. Fishbane S, Galgano C, Langley RC Jr, Canfield W, Maesaka JK. Reticulocyte hemoglobin content in the evaluation of iron status of hemodialysis patients. Kidney Int 1997; 52: 217-22. 


\section{Evaluation of iron status by serum transferrin receptor level}

Background: The purpose of this study was to estimate the value of the transferrin receptor in serum (STfR) for detecting iron deficiency and compare it with the value of some other blood tests for that purpose.

Material and methods: All patients undergoing bone marrow aspiration in the FSA Hospital, Akureyri, Iceland, in the period 1999 to 2003 were eligible to participate in this prospective study. Included participants were 89. The sensitivity, specificity, efficiency, and Youden index of ferritin, MCV, CHr, sTfR, sTfR-Ferritin-index, the iron saturation of transferrin, and the Thomas-Plot method were calculated. The complete absence of stainable iron in bone marrow was used as the definitive marker of iron depletion.

Thorsteinsson V, Yngvason FE.

Evaluation of iron status by serum transferrin receptor level. Icel J Med 2010; 96; 11-18.

Key words: iron deficiency, transferrin receptors, sTfR, reticulocyte hemoglobin content.

Correspondence: Vigfús Porsteinsson, aufus@simnet.is
Results: The best method to detect iron deficiency as estimated by the Youden index was the Thomas-Plot method. This method was very specific in cases without evidence of inflammatory processes (CRP $<6 \mathrm{mg} / \mathrm{L}$ ) and very sensitive in cases with elevated $\mathrm{CRP}(\geq 6 \mathrm{mg} / \mathrm{L})$. The sTfR-Ferritin-index came second and sTfR was the best single blood test to detect iron deficiency according to the Youden index.

Conclusion: The Thomas-Plot method and the sTfRFerritin-index proved to be the most reliable blood tests to diagnose iron deficiency. These parameters can eliminate the need of using bone marrow aspirate to diagnose iron defieciency in some cases.

Barst: 16. maí 2008, - sampykkt til birtingar: 13. nóvember 2009.

\section{CHAMPIX $^{\circledast}$ (vareniclin)}

Filmuhúðaðar töflur $0,5 \mathrm{mg}$ og $1 \mathrm{mg}$. Ábendingar: Hjá fullorðnum til að hætta reykingum. Skammtar: Hefja á meðferð samkvæmt eftirfarandi áætlun: Dagur 1-3: 0,5 mg einu sinni á sólarhring. Dagur 4-7: 0,5 mg tvisvar á sólarhring. Dagur 8-međferðarloka: $1 \mathrm{mg}$ tvisvar á sólarhring Heildartími meðferðar er 12 vikur. Skert nýrnastarfsemi: Lítið til í meðallagi mikið skert nýrnastarfsemi: Ekki parf að breyta skömmtum. Alvarlega skert nýrnastarfsemi: $1 \mathrm{mg}$ einu sinni á dag eftir priggja daga skammtaaðlögun (0,5 mg einu sinni á dag). Skert lifrarstarfsemi: Ekki parf að breyta skömmtum. Aldrađir Ekki barf að breyta skömmtum. Börn: Ekki er mælt með notkun handa börnum og unglingum yngri en 18 ára. Frábendingar: Ofnæmi fyrir virka efninu eða einhverju hjálparefnanna. Sérstök varnaðarorð og varúðarreglur við notkun: Aðlaga getur purft skammta hjá sjúklingum sem samtímis nota teófýllín, warfarín og og insúlín. Eftir markaðssetningu hefur verið greint frá punglyndi, sjálfsvígshugsunum, -hegðun og -tilraunum hjá sjúklingum sem reynt hafa að hætta reykingum með CHAMPIX. Ekki höfơu allir sjúklingar hætt að reykja pegar einkennin komu fram, ekki höfðu allir geđsjúkdóma fyrir sem vitað var um. Læknar ættu að vera meðvitaðrir um hugsanlega hættu á verulegum punglyndiseinkennum hjá sjúklingum sem reyna að hætta að reykja og ættu að leiðbbina peim m.t.t. pess. Hætta skal strax meðferð með ef læknir, sjúklingur, fjölskylda eđa aðstandendur verða varir við óróleika, geðdeyfð eða breytingar á hegðun eða ef sjúklingur fær sjálfsvígshugsanir eđa sýnir sjálfsvígshegðun. Geðđdeyfð, sem í mjög sjaldgæfum tilvikum hefur í för með sér sjálfsvígshugsanir og -tilraunir getur verið einkenni nikótínfráhvarfs. Að hætta að reykja, með eða án lyfjameðferðar, hefur einnig verið tengt við versnun undirliggjand geðsjúkdóma (t.d. punglyndis). Öryggi og verkun Champix hjá sjúklingum með alvarlega geð̌sjúkdóma eins og geðklofa, geð̌hvarfasýki og alvarlegt punglyndi hefur ekki verið rannsakað. Gæta skal varúđar við meðferð á sjúklingum með sögu um geðsjúkdóma og leiðbeina peim m.t.t. pess. Enginn klínísk reynsla liggur fyrir um notkun CHAMPIX hjá sjúklingum með flogaveiki.Við lok meðferða gætti aukinnar skapstryggðar, löngunar til að reykja, punglyndis og /eđa svefnleysis hjá allt að 3\% sjúklingar pegar međferð var hætt. Upplýsa skal sjúkling um petta og ræđa hugsanlega pörfá að minnka skammta smám saman í lok međferđar. Milliverkanir: Ekki hefur verið greint frá klínískt marktækum milliverkunum Iyfja við CHAMPIX. Meðganga og brjóstagjöf: CHAMPIXá ekki að nota á meðgöngu. Ekki er vitað hvort varencilin útskilst í brjóstamjólk. Meta skal hvort vegi byngra, ávinningurinn sem barnið hefur af brióstagiöfinni eða ávinningurinn sem móðirin hefur af CHAMPIX meðferơ, áður en ákveðið er hvort halda skuli brjóstagjöf áfram. Áhrif á hæfni til aksturs og notkunar véla: Champix getur haft lítil eðaa í međallagi mikil áhrif á hæfni til aksturs og notkunar véla. Á međan á meðferðinni stendur geta sjúklingar fundið fyrir sundli og syfju. Aukaverkanir: Pegar reykingum er hætt, hvort sem bað er gert með eða án lyfjameðferðar, geta komið fram ýmis einkenni, t.d. andleg vanlíðan og bunglyndi, svefnleysi, skapstyggð kvíði, einbeitingarskortur, eirðarleysi, hægur hjartsláttur, aukin matarlyst og pyngdaraukning. İ klínísku rannsóknunum var ekki aðgreint, hvort aukaverkanirnar voru vegna fráhvarfseinkenna nikótíns eða tengdust notkun viðkomandi meðferðarlyfs. İ klínískum rannsóknum með Champix voru u.p.b. 4000 sjúklingar með̌höndlaðir í allt að 1 ár. Aukaverkanirnar voru vægar eða í meðallagi slæmar og komu almennt fram á fyrstu viku meðferðar. Mjög algengar aukaverkanir (>10\%): Ógleđi, höfuðverkur, óeðlilegar draumfarir, svefnleysi. Algengar aukaverkanir $(>1 \%$ og $\leq 10 \%)$ : Aukin matarlyst, syfja, sundl, röskun á bragð̋skyni, uppköst, hægðatregða, niðurgangur, upppemba, magaópægindi, meltingartruflanir, vindgangur, munnpurrkur og preyta. Auk pess hefur sjaldan veriơ greint frá $(\geq 0,1 \% \circ \mathrm{og}<1 \%)$ gáttatifi og brjóstverkjum. Ofskömmtun: Veita skal stuð̋ningsmeðferð eftir börfum. Pakkningar og verð 1. desember 2009: Upphafspakkning ( $0,5 \mathrm{mg} 11 \mathrm{stk}+1 \mathrm{mg} 42 \mathrm{stk}$ ): 18.715.- 8 vikna framhaldspakkning (1mg, 112 stk): 32.029.- Lyfið er lyfseððilsskylt og greiðist skv. greiðslufyrirkomulagi 0 í lyfjaverðskrá. Handhafi markaðsleyfis: Pfizer, Vistor hf., Hörgatúni 2, 210 Garðabær. Samantekt um eiginleika lyfs er stytt í samræmi við reglugerð um lyfjaauglýsingar. Upplýsingar um lyfið er að finna í sérlyfjaskrá og á lyfjastofnun.is.

\section{Heimildir:}

1. Gonzales D et al. Varenicline, an a4ß2 nicotinic acethylcholine receptor partial agonist, vs sustained-release bupropion and placebo for smoking cessation. A randomized controlled trial. JAMA 2006; 296(1):47-55. 2. Jorenby DE et al. Efficacy of varenicline, an a4ß2 nicotinic acethylcholine receptor partial agonist,vs placebo or sustained-release bupropion and for smoking cessation. A randomized controlled trial. JAMA2006; 296(1):56-63. 